\title{
Analysis Grid of Adjustment Strategies of Non-profit Organizations Benefiting From Microcredit to the Constraints of Microfinance Institutions: The Case of Burundi
}

\author{
Marie-Goreth Nduwayo ${ }^{1} \&$ Michel Sayumwe ${ }^{1}$ \\ ${ }^{1}$ University of Quebec at Montreal, Montreal, Quebec, Canada \\ Correspondence: Michel Sayumwe, University of Quebec at Montreal, Montreal, Quebec, Canada.
}

Received: April 21, 2018

Accepted: June 4, 2018

Online Published: June 19, 2018

doi:10.5430/ijfr.v9n3p86

URL: https://doi.org/10.5430/ijfr.v9n3p86

\begin{abstract}
Based on the work of Henderson and Venkatraman (1993) on strategic alignment, the objective of this article is to explain that the strategic alignment of microcredit beneficiary not for profit Organizations (NPOs) is achieved through their adjustment to the constraints of their lessors. We thus discuss the adaptation of Burundian NPOs benefiting from microcredit by taking into account a specific attribute of a difficult economic environment: the threat of their survival. The physiological needs of their members are at the origin of their reactions of adaptation to the constraints of the lessor. This adaptation enables them to acquire and maintain the resources necessary for their survival. This article explains this adaptation by highlighting the strategic actions of the members of the NPOs who are beneficiaries of microcredit.
\end{abstract}

Keywords: not for profit organizations, adjustment strategies, microfinance institutions, microcredit, Burundi

\section{Introduction}

In the absence of a general theory of strategic alignment and a definition accepted and shared by all researchers and practitioners, it is necessary to delineate the contours of the concept of strategic alignment which, despite everything, remains unclear. To achieve this goal, it is important to present the framework of reference for strategic alignment developed in the management literature. Thus, despite the vast literature on the contribution of microfinance institutions to the development of microenterprises, little is known about their adaptation to the requirements of their lenders. Choosing a relevant view of strategic alignment allows us to analyze the strategic fit that is one of the aspects. This allows us to propose a model of contingent adjustment of the object of analysis.

In this research, we need to understand if the members of the NPOs benefiting from microcredit adapt their actions to the constraints of the MFIs. We first show the main requirements of Burundian microfinance institutions that are the lessors of these NPOs. We then explain the adaptation of microcredit beneficiary NPOs by proposing an analysis grid of their strategies to comply with these requirements. This analysis is followed by a discussion of the strategies for formalizing the operating and compliance procedures of these non-profit organizations to adapt to the constraints of the microfinance institutions.

This article is structured as follows. The second section will deal with the theoretical framework and the review of the literature before describing the methodological framework and the results in the third and fourth sections. We discuss the results in section 5 and conclude the article in the section 6.

\section{Theoretical Framework and Literature Review}

To explain the link between the strategic alignment of a NPO and the constraints of microfinance institutions, we start from the reference framework devised by Etien (2006) and Thevenet (2009). These authors suggest to consider alignment in general and strategic alignment in particular according to four views.

\subsection{Theories of Strategic Alignment: Outlines and Relevance}

According to Etien (2006) and Thevenet (2009), each view makes it possible to analyze a particular aspect of the alignment by analyzing four fundamental questions that are those of "what", "why", "how", and finally "by what means". They allow respectively to focus on the purpose of the strategic alignment, that is to say the entities that we 
seek to align and the links between these entities, the goals of the approach alignment, the method used to achieve these goals and the tools used.

In relation to the "object", the aspects that characterize the alignment approaches result from the fact that the latter implies by nature several entities to align. It takes at least two and there must be relationship between them.

Concerning the "purpose", two types of evaluation exist. On the one hand, there are approaches that measure alignment to justify its relevance. On the other hand, there are researching approaches that help understand and measure alignment to help the company improve its current situation. This first type of approach is geared towards management.

The "method" view, used in alignment approaches, depends on the goal to be achieved. In our analysis, we choose the strategic adjustment method by adopting a dependency approach. Through this approach, we study the links of dependence between key strategic variables and survival goals of Burundian NPO beneficiaries of microcredit. This dependency approach focuses on the organizational context and the reasons for resource dependence. The strategic adjustment method explains not only the alignment, but also the dependency between the perspectives of organizational effectiveness and the strategic goals of these NPOs. The elements we are studying are therefore largely the goals, resources and strategies that we link to each other with environment-purpose relationships.

Finally, compared to the "tool" view, the "Balanced Scorecard" model is a strategic instrument that has been adapted to information technologies. It comprises four axes: the financial axis, the customer axis, the organizational learning axis and the internal processes axis. Objectives are defined for each axis, refined and linked together by contribution links (Kaplan and Norton, 1992).

The relevance of strategic alignment is particularly emphasized by Henderson and Venkatraman (1993) who see it as a process of continuous adaptations and changes to ensure harmony between business strategy and global strategy. Miles and Snow (1984), for their part, consider that the concept of alignment is a process and a state. They emphasize that fit can be analyzed as a dynamic search that aims to align the organization with its environment and to organize resources internally.

This is the reason why Venkatraman and Camillus (1984) addressed the issue of the shape of alignment. They wondered whether to consider this concept as a static or dynamic phenomenon. They argued that measures based on the static form have the advantage of being considered as the fastest way to identify the most important variables that should be in alignment.

The strategic alignment concept has many pseudonyms. It is also called "adjustment" (Zimmermann and Stevens, 2006), "integration" (Monnoyer-Longé and Madrid, 2007), "bridge" or "assembly" (Zimmerman, 2002). However, in all cases, it concerns the integration of strategies relating to the activity of the company. Thus, regardless of the author, the literature on strategic alignment is based on the existence of an organization that interacts with its environment. Venkatraman (1989) complements his colleagues by proposing another typology of the broader and more comprehensive adjustment concept. He identifies six categories, which are adjustment as a moderation, as a mediation, as a pairing, as a profile deviation, as a gestalt and finally as a covariation.

Six contingent adjustment perspectives describe the different adjustment possibilities and the different variables involved in the contingency models. They focus on a static approach in which alignment can be tested and measured from statistical methods. In noting its static nature, the author recognizes that the measure of quota adjustment by statistical methods excludes its dynamic nature (Venkatraman, 1989). Despite this limitation, the different adjustment perspectives have been widely used in management science to examine relationships between organizations and their contexts.

\subsection{Strategic Adjustment Model for Microcredit Beneficiaries}

The theory of contingency was developed in the late 1950s and in the 1960s. This theory is based on so-called contingent propositions and assumptions, according to which organizational performance is the consequence of coherence between two or more factors such as environment, structure and technology (Burns and Stalker, 1961).

A number of models of strategic alignment have been proposed. Among these many models, the most important is the Strategic Alignment Model (SAM) of Henderson and Venkatraman (1999). These authors have proposed a strategic alignment model based on a systemic approach and stress the importance of aligning internal and external business domains with the enterprise. They also believe that alignment between these areas should improve organizational performance. Thus, it does not matter whether the change comes from the business strategy or is 
caused by the possibilities offered by information technology. It is the result of the alignment of all these aspects that is important.

Our strategic adjustment model thus has its roots in the work on the strategic alignment of Henderson and Venkatraman (op.cit.). It is built on four fundamental areas of strategic choice: the specificities of intervention of microfinance institutions, the requirements of the lender, the adaptation strategies and the internal integration of non-profit organizations that benefit from microcredit.

We choose to give this concept a sense of finality in our analysis of strategic adjustment. In this sense, the adaptation of means to ends, starts from an internal principle to any organization that tends to a goal (Jakubowicz, 2002). To this end, a strategic adjustment is formed in response to two major challenges facing any organization according to Papp (2001): external adaptation and survival as well as internal integration.

By adaptation, Hellriegel and Slocum (2006) discuss the ways in which the organization adapts to the external environment in which it lives. According to these authors, external adaptation and survival assume to focus first on the mission and the strategy by identifying the major objective of the organization. Thereafter, the focus is on the objectives by identifying specific goals to be achieved. Finally, it is necessary to think of the means by the determination of the modes of pursuit of the objectives in particular by the selection of a mode of financing.

Integration, for its part, has two fundamental aspects that cannot be dissociated. The first is the maintenance of effective working relationships among the members of an organization (Papp, 2001; Hellriegel and Slocum, 2006). The second is related to how these members are effective in their respective activities; the search for efficiency in the exercise of everyday activities is a common problem for any company. According to Rousseau (2001), for example, internal integration involves the identification of communication methods and the establishment of membership criteria for groups and teams.

\subsection{Strategies of Burundian NPOs Benefiting From Microcredit in the Principle of Diversification of Activities}

In the empirical research in performance management, the strategy was considered an important (internal) contextual factor. Thus, we are witnessing the development of a new conception of rationality. Laville $(1999,2000)$ and Chiapello and Desrosières (2006) go in this direction by making behaviors in particular an object of study in itself and not as a simple means of the theory of markets and prices as advocated by Friedman (2004). They take into account uncertainty and imperfect information as well as the interdependence of agents. The latter make their decisions by anticipating the actions of others. These actions are described as strategic behaviors (Bazzoli and Dutraive, 2006).

Most authors in management including Boyer et al. (2005) and Hellriegel and Slocun (2006) differentiate the design and formulation of a strategy from its implementation. These authors support the ideas of their predecessors (Mintzberg and Waters, 1985) and argue that the strategy can be conceived in four main ways: a plan, a perspective, a position and a pattern. These different ways of conceiving the strategy must take into account both the environment, the skills of the organization and the role of the actors. The chosen strategy thus acts as a lever that makes it possible to improve performance.

Strategy formation can come from two different processes. Strategies can be formed by using a formalized analytic process even before the action takes place. This is called a strategic planning process. Whatever the stage of the strategic process, the idea of strategy is often used to describe and understand the behavior of organizations (Chiapello and Desrosières, 2006). This statement is valid for all organizations, whether they are non-profit organizations or private companies (Stajkovic and Luthans, 1997). Strategies can also be formed in action. This is known as an emerging strategy, groping strategy and daily strategy (Porter 1980, Hafsi et al 2000). The strategy is built in the latter case through a set of actions that determine what it consists.

In this sense, heterodox economists like Lavoie (2005) and Lawson (2007) attribute three essential functions to the entrepreneur. The first is the function of innovation or creation in which the company seeks to act on its environment. The other two are the function of acquisition and exploitation of information (Hayek, 2002) and a function of organization and coordination of production (Müller et al, 2004). In our analysis, we will examine this first function in depth. This function is of particular interest to us because strategic alignment occupies an important place in our theoretical corpus.

Diversification is one of the most important strategies of alignment (Chandler and Hikino, 2009). In fact, the diversification of a business is its opening up to activities, markets or new territories compared to what it has been practicing until then. In most cases, a narrow definition of diversification limits this concept to the diversification of markets and products. This is the case of the corporate strategy developed by Ansoff (1965) in particular, which 
proposes the orientation towards new products and new markets. But the word diversification is used today to refer to many things. Thus, we distinguish developmental diversification (Research and Development), functional diversification, geographical diversification (international), and diversification of financing resources (Séguin et al, 2008).

The majority of diversification studies are in the area of market finance through portfolio diversification in particular. But, whatever the field, there are many reasons for the diversification of activities. We retain three most important reasons. The first is related to the fact that diversification is often stimulated by the presence of surplus resources (Séguin et al., op.cit.). The desire to use these resources effectively drives the company to make an appropriate strategic choice. We find that this efficiency is one of the important reasons why companies diversify their activities.

Diversification can be done through internal development or acquisition. The first form uses the company's internal resources as a basis for new activities. This kind of diversification presupposes an organizational capacity to protect and develop new activities (Séguin et al, 2008). In this case, internal diversification by launching new activities or by prospecting new areas relies on the means of the company. A merger or acquisition diversification is a strategy to optimize the use of resources. External diversification through the acquisition of other companies takes place in a different sector of activity. It is present in large companies and reduces the cost of entry into a new industry.

A second important reason for the decision to diversify is the need for growth. Diversification is one of three growth strategies: specialization, vertical integration and diversification. Specialization means focusing on a single product for a single market using a single technology. However, specialization does not exclude a certain variability of products. Vertical integration is the acquisition operation by which the company takes control of either a supplier or a customer.

Diversification is about increasing the range of products and services the company produces. It can be stimulated by factors such as the appearance of opportunities or threats. In this case, the motivation for diversification is to spread the operating risks, take advantage of opportunities and, if possible, achieve synergies. One last very important motivation is to compensate for a decline in the profitability of the company's traditional activities and prepare for its conversion. But the risk of diversification is that of the scattering of resources and the difficulty of mastering several trades. In short, we hold that the goal of diversification is twofold: the search for synergies or economies of scale and the distribution of risks (Robbins and DeCenzo, 2004).

\section{Methodological Framework}

Different approaches can be taken to administer a questionnaire: (i) sending it to respondents by mail, (ii) electronically, or (iii) administered directly to respondents. We chose the approach that seemed most convenient to interviewees, namely the direct administration of the questionnaire to respondents. The questionnaire is a primary data collection tool well suited to quantitative research as it allows for the processing of large samples. It also makes it possible to establish statistical relations or numerical comparisons (Baumard et al, 2003).

We thus came up with a questionnaire that we submitted to a pretest before its administration to our sample. The pretest is an important phase and is necessary in order to test the form of the questions and their sequencing. It makes it possible to check the respondents' understanding as well as the relevance of proposed response modalities (Baumard et al, 2003). As part of this research, we tested our questionnaire with a dozen microcredit beneficiary organizations operating in Bujumbura, the Capital City of Burundi. The pretest with these associations has been of considerable contribution. It has indeed allowed a significant improvement of our questionnaire before administering it to our sample distributed in all the provinces of Burundi.

Through the various interviews we conducted with Burundian NPOs benefiting from microcredit, we found a homogeneity of responses. While we planned to interview an official of the association and his assistant, we were faced with similar answers. We opted to interview only the chief officers or the deputy in case of absence of the first.

The documents used consist mainly of reports on the situation and financial statements of microfinance institutions. Other documents related to the operating policies (savings, credit, investment, development, etc.), the statutes and bylaws have been very useful.

These various documents have helped us a lot in identifying the logic of action pursued and their dynamics over time. Sometimes, we had to look for additional information by consulting documents related to the history and socio-economic context of Burundi. 


\subsection{The Survey of Managers of NPOs Benefiting From Microcredit}

To get an idea of how the Burundian NPOs benefit from microcredits, we based the collection of data on the administration of a questionnaire. We conducted a series of direct interviews with a sample of 150 NPOs benefiting from microcredit. To collect information on the activities of members of these NPOs, we used two tools and two techniques. Regarding the tools, we carried out a documentary analysis and direct interviews with this sample. Compared to the techniques, several methods of strategic alignment are possible. We distinguish two major modalities of adjustment. The strategic approach is one of the modalities of an adjustment to the strategic stakes of an organization. In the case of NPOs that benefit from microcredit, they try to adapt to the socio-economic context in the long term. The resource approach is the other modality that particularly interests us even if it is aimed at the short term. In this case, these NPOs try to obtain the necessary financial resources to maintain and develop their activities.

Unfortunately, the study of NPO strategies is a delicate methodological issue (Richez-Battesti and Oswald, 2010). And for the specific case of Burundian NPOs benefiting from microcredit, the methodological issue is complicated because the leaders of these NPOs have for the most part a very low level of education. Thus, the method adopted is to formulate closed questions of a general nature on five dimensions of organizational effectiveness. A questionnaire comprising three parts was sent to the managers of NPOs who are beneficiaries of microcredit. The first part identifies the main characteristics of the respondents. The second part of the questionnaire aims to analyze the participatory dynamics of the association. The third part concerns the adaptation of these associations to the loan methodology of microfinance institutions.

In addition to the constraint mentioned above, economic information is unfortunately unavailable for most very small and small Burundian companies. These are not in fact recorded in the usual databases. Apart from that, the accounting data of these micro enterprises do not exist. And for the particular case of non-profit micro-credit NPOs, most members are illiterate. Although some members have mostly participated in literacy programs, few people keep an account book. They are convinced that they calculate and remember everything mentally. To circumvent all these difficulties as well as the problem related to the lack of a directory of associations financed by microfinance institutions, we asked them to give us the program of their visits. This allowed us to interview the leaders of the associations after the meeting of the members. We interviewed 72 NPOs funded by savings and credit cooperatives and 46 NPOs funded by microcredit programs. The remaining 32 non-profit organizations are financed by microfinance companies.

Both approaches to data collection (strategic approach and resource approach) are not mutually exclusive (Helfer et al, 2004). For this, we were able to analyze the adjustment strategies of Burundian NPOs who are beneficiaries of microcredit with regard to the constraints of the lender.

\section{Results}

Microcredit provides through income-generating activities, which enable members of Burundian NPOs who benefit from microcredit to survive. Unfortunately, the environment of these nonprofits is a constraint for their organizational actions. Indeed, the irruption of the financial contingency questions these NPOs in the performance of their projects and forces them to respect their commitment to the lessor.

\subsection{Characteristics of the Group Microcredit}

To benefit from the first loan, one must meet the following conditions: be a member of the association, live or work in a territorial area of the MFI, be of age, inspire confidence and be solvent.

Members of NPOs use financial services to meet their physiological needs in large part. These financial services are limited to savings and credit. Here, we discuss one of these financial services: credit. Applied to our case study, we analyze group microcredit.

Proximity is a very important element in the way in which Burundian NPOs benefit from microcredit. We note in fact that these associations are made up of $65.3 \%$ of people from the same social background. Relationships between members are essentially neighborhood ones. This promotes meetings of members whenever necessary. The remaining $34.7 \%$ are made up of members who practice the same profession, especially trade.

It's important to note that loans to NPOs are granted individually by the microfinance institution to each member of the association. Thus, the constitution of a group of at least two people is required to access to group microcredit.

Members of NPOs benefiting from microcredit do not have real guarantees. Microcredit is then backed by other forms of guarantee. The most common forms are: the joint surety and the material goods to which members of an association are attached (fields, parcels, livestock, etc.). In the event of difficulties for a member of a NPO who is a 
beneficiary of microcredit, the other members are able to implement a certain solidarity. The only condition is that the sums involved are small and the defaulting borrower has encountered real problems.

The repayment guarantee varies according to the type of MFI. For example, in the case of savings and credit cooperatives, if a member cannot repay, it is the other members who have to pay his loan. The money-back guarantee is constituted by a strong social pressure exerted on the members of the association. It is in a way an incentive to honor their commitment and to monitor each other.

At the request of the members of the association, a first loan of a certain amount is granted according to the needs expressed by different members. If this loan and hence the group loan is repaid on the agreed date, another loan of higher amount is granted, and so on. Microcredit help beneficiaries to develop an activity that generate a modest income. Granted for a maximum of one year at the rate of $18 \%$ to $36 \%$, they begin to be reimbursed as early as the second week. When group credit is repaid, members of the group can borrow a little more.

Members of microcredit associations save before and after the moment when they have access to a large amount of money. Only savings and credit cooperatives and microfinance companies are allowed to collect savings. Microcredit programs are only allowed to collect deposits from their clients. Although savings are considered in this case as part of the credit product, they are not included in our analysis. The principle of increasing loan renewal can only be effective for very small activities. Thus, faced with an offer often unsuitable for their income-generating activities, Burundian NPOs benefiting from microcredit implement strategies to adapt to the requirements of financing MFIs.

\subsection{Adjustment Strategies for Non-profit Organizations Benefiting From Microcredit in Burundi}

The strategies of Burundian NPOs benefiting from microcredit can be analyzed at two levels. At the corporate strategy level, members' adaptive behavior is proactive (Greffe and Simonet, 2008). For this, we adopt the approach of Orlove (2005) which proposes a strategy based on the interactions between the actors to develop a strategy rooted in an organization. From this perspective, we show (Table 1) that the frequency of meetings is one of the determinants of the adjustment of members of NPOs who are beneficiaries of microcredit to the constraints of the lender. Generally, these NPOs are organized around five key variables: the dominant gender, the size, the nature of the income-generating activity, the diversification of activities and the frequency of meetings. Depending on the type of MFI, and depending on the activity carried out, women make up almost all the members of these NPOs.

The ability of members of NPOs who benefit from microcredit to improve their living conditions is the main determinant of their organizational effectiveness. However, such an opportunity passes through the faculty of these NPOs to integrate the dynamism (see table below) in their income-generating activities.

Table 1. Table of contingency of the frequency variable of the meetings and the objective variable of the nonprofit

\begin{tabular}{lllll}
\hline \multirow{2}{*}{ Primary Objective } & \multicolumn{4}{l}{ Meetings Frequency } \\
\cline { 2 - 5 } 1= Social Assistance & Weekly & Bi-weekly & Monthly & Non Regular \\
\hline 2= Financial Assistance & 14 & 1 & 0 & 0 \\
\hline 3= Production of goods and services & 8 & 2 & 0 & 0 \\
\hline 4= Satisfaction of needs & 18 & 12 & 22 & 21 \\
\hline
\end{tabular}

Source: Authors from the survey data

Although some members of NPOs do meetings once a month, their purpose is either to produce primary goods or to meet physiological needs. The same is true of members who hold meetings irregularly. Dynamism in itself allows the implementation of organizational efficiency. This determinant demonstrates that the thesis of dynamism favors in its analysis of organizational effectiveness, the frequency of meetings of the members of these NPOs.

As part of the business strategy, these NPOs try to diversify their income-generating activities. Thus, the diversification of activities is one of the survival strategies put in place by these NPOs.

In the contingency table below, we show the objectives targeted by NPOs who benefit from microcredit through the diversification of income-generating activities. 
Table 2. Table of contingency of the diversification variable of the activities and the principal objective variable

\begin{tabular}{|c|c|c|c|c|c|c|c|}
\hline \multirow{2}{*}{ Primary objective } & \multicolumn{7}{|c|}{ Activities Diversification } \\
\hline & $\begin{array}{l}\text { Agriculture } \\
\text { alone }\end{array}$ & $\begin{array}{l}\text { Agriculture- } \\
\text { commerce }\end{array}$ & $\begin{array}{l}\text { Agricultur } \\
\text { e-hearstyle }\end{array}$ & $\begin{array}{l}\text { Comerce } \\
\text { alone }\end{array}$ & $\begin{array}{l}\text { Commerce- } \\
\text { agriculture }\end{array}$ & $\begin{array}{l}\text { Commerce } \\
\text {-Others }\end{array}$ & Others \\
\hline 1= Social Assistance & 1 & 1 & 1 & 3 & 3 & 2 & 4 \\
\hline $\begin{array}{l}2= \\
\text { Assistance }\end{array}$ & 0 & 0 & 0 & 2 & 0 & 2 & 1 \\
\hline $\begin{array}{l}3=\text { Production of } \\
\text { goods and services }\end{array}$ & 27 & 19 & 5 & 0 & 0 & 0 & 1 \\
\hline $\begin{array}{l}4=\text { Satisfaction of } \\
\text { needs }\end{array}$ & 0 & 2 & 0 & 28 & 30 & 13 & 5 \\
\hline
\end{tabular}

Source: Author from the survey data

Agriculture, whether carried out alone or with another income-generating activity, targets the production of primary goods. Trade on its own, whether on its own or with another income-generating activity, is aimed at satisfying physiological needs.

Other combinations of income-generating activities, other than those mentioned above, are for financial or social assistance.

Instead of the cut between rural and urban, hierarchical nodes appear (rural towns, secondary cities and capital) with rural areas, themselves differentiated according to their distance from major cities. This is why we distinguish between the city center of the Burundi capital and the cities of the other provinces. In addition, we distinguish the outskirts of the city of Bujumbura (capital of Burundi) of the countryside located far from the provincial capitals.

Table 3. Objectives of the NPO as a function of distance from power (capital of Burundi)

\begin{tabular}{lllll}
\hline \multirow{2}{*}{ Primary Objective } & Impact Zone & & & \\
\cline { 2 - 5 } & $\begin{array}{l}\text { Bujumbura-Do } \\
\text { wntown }\end{array}$ & $\begin{array}{l}\text { Bujumbura-Ot } \\
\text { her areas }\end{array}$ & $\begin{array}{l}\text { Cities-Other } \\
\text { Provinces }\end{array}$ & Rural areas \\
\hline 1= Social Assistance & 0 & 6 & 1 & 8 \\
\hline 2= Financial Assistance & 1 & 2 & 1 & 1 \\
\hline 3= Production of goods and services & 3 & 3 & 2 & 44 \\
\hline 4= Satisfaction of needs & 12 & 6 & 28 & 32 \\
\hline
\end{tabular}

Source: Authors based on survey data

Trade loans show the strategies of different types of traders and their areas of influence. In the Burundian capital to a lesser extent and in large urban centers especially, there is short-distance trade with rapid resale. There is also trade in one or more products and commerce focused on the supply of the capital or provincial cities, or long distance within the country. In the countryside, the members of NPOs benefiting from microcredit successively target the production of primary goods and the satisfaction of physiological needs.

\section{Discussion}

Prahalad and Hamel (1990) find that successful firms are those that adapt and seize opportunities that are inaccessible to others. Their work stimulated many researchers who wanted to know if there was a systematic link between the nature of resources and success. This gave rise to what Wernefelt (1984) called the resource perspective. According to the latter, resources can not be considered without reference to the environment (Prahalad and Hamel, 1989). 
Compared to the resources of NPOs who benefit from microcredit, microfinance institutions favor certain types of income-generating activities that require small amounts of investment. This often directs microcredit-focused NPOs to trade, which allows a quick return on investment to meet the repayment schedule.

The following table (Table 4) shows the activities carried out by the members of the microcredit beneficiary associations by category of microfinance institution.

Table 4. Distribution of microcredit beneficiary associations according to the type of MFI and the nature of the activity carried out

\begin{tabular}{|c|c|c|c|c|c|c|c|c|c|}
\hline \multicolumn{9}{|l|}{ Nature of activity } & \multirow[t]{2}{*}{ Total } \\
\hline Type of MFI & 1 & 2 & 3 & 4 & 5 & 6 & 7 & 8 & \\
\hline $\begin{array}{l}\text { Savings and credit } \\
\text { coop }\end{array}$ & 51.39 & 45.83 & 1.39 & 0 & 1.39 & 0 & 0 & 0 & 100 \\
\hline Microcrédit Program & 29.03 & 51.61 & 3.23 & 12.9 & 0 & 3.23 & 0 & 0 & 100 \\
\hline Microfinance Company & 10.64 & 78.72 & 4.26 & 0 & 0 & 0 & 4.26 & 2.13 & 100 \\
\hline Total & 34.00 & 57.33 & 2.27 & 2.67 & 0.67 & 0.67 & 1.33 & 0.67 & 100 \\
\hline
\end{tabular}

Source: Authors from the survey data

Nature of activity: $1=$ Agriculture; $2=$ Trade; $3=$ Sewing; $4=$ Education at the primary level; $5=$ Motorcycle riding; $6=$ Hairstyle; $7=$ Bus driving and $8=$ Photocopy and printing

The activities that are much more financed by Burundian microfinance institutions are in order of importance trade and then agriculture. These activities take up most of the microloans granted by MFIs. They are financed respectively at $57.33 \%$ and $34 \%$. If we go into more detail, we note that savings and credit cooperatives (Coopec) finance $51.39 \%$ of agriculture and $45.83 \%$ of trade. The other two categories of MFIs and above all microfinance companies (SA) finance trade more than agriculture.

Table 5. Table of correlations of the MFI category variable and the objective variable of the non-profit organization

\begin{tabular}{llll}
\hline \multirow{2}{*}{ Primary Objective } & \multicolumn{2}{l}{ Category of MFI } & \\
\cline { 2 - 4 } & $\begin{array}{l}\text { Savings and credit } \\
\text { cooperative }\end{array}$ & $\begin{array}{l}\text { Microcredit } \\
\text { program }\end{array}$ & $\begin{array}{l}\text { Microfinance } \\
\text { company }\end{array}$ \\
\hline 1= Social Assistance & 0 & 15 & 0 \\
\hline 2= Financial Assistance & 0 & 5 & 0 \\
\hline $3=$ Production of goods and services & 38 & 7 & 7 \\
\hline $4=$ Satisfaction of needs & 34 & 4 & 40
\end{tabular}

Source: Authors from the survey data

Through the use of savings and credit cooperatives, members of micro-credit NPOs target the production of primary goods and the satisfaction of physiological needs at the same time. While by using microfinance companies, the members of these NPOs aim to meet the physiological needs. Microfinance companies are close to satisfying physiological needs, while savings and credit cooperatives are close to the production of primary goods. Microcredit programs, on the other hand, favor the social and financial assistance of their clients grouped together in associations.

The resource dependency model and the stakeholder perspective underlie our analysis of the environment and its links with Burundian NPOs that benefit from microcredit. Indeed, their resources and their stakeholders cannot be considered without reference to their economic and financial environment. In this sense, we will discuss below two methods widely used in strategy to propose a grid of analysis of the strategies of NPOs benefiting from microcredit. This is the model of resource dependence (Pfeffer and Salancik, 1978) and the perspective of actors (Porter, 1980). 
Through these two methods, we show below that Burundian NGOs benefiting from microcredit develop specific modes of organization to adapt to their requirements.

The financial requirements of Burundian microfinance institutions are to make a rigorous analysis of loan applications as they must be repaid. Their organizational requirements are related to the lending process. These allow them to function effectively in the sense of their strategy of sustainability. Thus, they adopt a variety of methods to obtain the loan repayment. The lending process depends on the target clientele and the loan amount. Also, the process varies depending on whether it is a first loan or a renewal. In the first case, microfinance institutions generally do not accept credit to associations until they have an idea about the profile of their members.

Whatever the criterion, the entire lending process is rigorous but fast. The processing time for the requests for credits do not generally exceed 15 days.

The table below highlights the strategies adopted by members of these NPOs to adapt to the requirements of MFIs. The adaptation of these NPOs to the constraints of the MFIs allows them to survive thanks to their access to financing that results.

Table 6. Analysis grid of the main adaptation strategies of microcredit beneficiary NPOs surveyed to the requirements of microfinance institutions

\begin{tabular}{ll}
\hline The requirements of MFIs & Strategies of members of NPOs who benefit from microcredit \\
\hline Financial Requirements & \\
\hline $\begin{array}{l}\text { 1. Small loan amounts and very short } \\
\text { repayment terms }\end{array}$ & Member projects that provide the money back guarantee \\
\hline 2. Project Analysis & Choice of AGR type: essentially trade credit \\
\hline $\begin{array}{l}\text { 3. Use of credit } \\
\text { Organizational Requirements }\end{array}$ & Even if their use is free, all loan credits are invested in a microenterprise \\
\hline 4. Nature of the AGR & Size of the variable association according to the type of AGR \\
\hline 5. Repayment incentive & Solidarity group mechanism \\
\hline 6. Refund & The members of the non-profit organization agree to pool the risks of \\
& mutual guarantee \\
\hline 7. Governance & Regular Meetings of members \\
\hline 8. Sustainability & Saving through income diversification \\
\hline
\end{tabular}

Source: Authors based on interview and survey data

For Boyer et al. (2005), the implementation of strategies involves the mobilization of different skills, specific resources and modes of particular organizations. Thus, the modes of organization of NPOs that benefit from microcredit interest us more particularly and are subject to this analysis grid above.

To adapt to the requirements of financing MFIs, microcredit beneficiary associations adopt two main types of strategies. These strategies concern the adaptation to small amounts of loans and short repayment periods especially. Unfortunately, a small amount does not fund the merchant's working capital requirements. It is also unsuitable for financing agriculture. In fact, agricultural activities require loan products adapted to the seasonality of harvests.

Among the strategies that allow them to adapt to the financing modalities of the lender, the joint and several guarantee is a social guarantee. The members of the NPOs who benefit from microcredit take care of the preparation of the projects that provide the guarantee of reimbursement. Indeed, the members of the group stand in solidarity in case of non-reimbursement. This is why members of certain associations are obliged to meet regularly because everyone needs to be aware of the situation of other members. The project itself is considered as the first guarantee.

Short-term credit granted by MFIs can only finance the short-term income-generating activities of micro-credit NPOs because of its nature. Thus, to try to adapt to the offer of MFIs, the members of these NPOs are asking for credit mainly for trade and agriculture to a lesser extent. Indeed, as microcredit loans are small ones, they are used to 
finance very small productive activities (working capital). Fortunately, with these financing arrangements, the members of such an association also feel more bound by solidarity.

Even if the choice of the use of credit is left to the borrower, all members of NPOs who benefit from microcredit use the loan to produce goods and services. Members of these NPOs cannot acquire productive assets, nor build or renovate their own homes with small amounts.

In relation to the organizational requirements, the borrowers constitute themselves in solidarity groups, of variable size according to the nature of the activity. Associations are constituted not in the light of the facilities that microfinance institutions offer to members to access credit but on a solid basis with, above all, a strong involvement of the beneficiaries. In addition, the mechanism of the solidarity group, generally consisting of 3 to 10 people, reduces the risk of default by simple reimbursement incentive process.

Loan guarantee mechanisms are therefore based on a group of joint and several guarantors. Hence the choice of members of NPOs who benefit from microcredit is made between neighbors, according to family relationships or according to the similarity of activities carried out. NPOs are also mostly based on socio-cultural parametric criteria: membership in the same profession or in the same area of residence. It is also common for workmates or neighbors to form rotating savings and credit groups to help each other.

The diversification of activities reduces the risks inherent in a single activity (often agriculture). In this case, the members of NPOs benefiting from microcredit opt for a strategy of diversification of activities because it brings not only new sources of income to the members, but also contributes to the strengthening of their survival.

The other factor behind the adjustment strategies of Burundian NPOs benefiting from microcredit is related to the risks they face.

We discuss the risk related to the expected performances and the financial risk.

Concerning the expected performances, the agricultural activities entail significant risks for NPOs who benefit from micro-credits. These risks include major climatic hazards, low profitability and risks related to the uncertainty of prices of agricultural products. As climate risk and transaction costs are very high, farmers are subject to instability and the vagaries of agricultural production which can lead to a low reimbursement rate. As a consequence, these low incomes make difficult to repay the loan. This leads to problematic access to financing by farmers. This problem is reinforced by the fact that, apart from savings and credit cooperatives, other microfinance institutions do not want to invest in the agricultural sector because of the random nature of agricultural production.

This clarified, it is now necessary to question the risks linked to the dependence on resources of which the members of the nonprofit organizations of microcredit are subject. Risks related to resource dependence are diverse. They range from insolvency risk, interest rate risk and liquidity risk. We first mention the risks of insolvency because the beneficiaries of microcredit sometimes have problems of repayment of credits. To maintain a credit image, the members of these NPOs do not borrow for consumption, but to develop an income-generating activity.

More in rural areas than in urban areas, the establishment of microfinance institutions has somewhat disrupted traditional economies. In African societies, in fact, financial systems are anchored in economic and social environments that prohibit the dissociation of economic and social accumulation. Despite this generalization on African societies, all microcredit beneficiaries in Burundi claim to have used their credit to finance an income-generating activity.

By applying for credits, the objective of the members of NPOs who benefit from microcredit is to invest the amount in an economic activity. It is very rare that a credit is intended for consumption.

\section{Conclusion}

Although Henderson and Venkatraman's (1993) work on strategic alignment has paved the way for a number of studies to determine the impact of strategic alignment on corporate organizational performance, there is a lack of consensus in the literature. We explore this field by taking into account a specific attribute of a difficult economic environment: the threat of survival of Burundian NPOs that benefit from microcredit. Thus, our analysis shows that the strategic alignment of these NPOs is achieved through their adjustment (taken in the finality sense or state that is different from the process) to the constraints of their lessors. In this article, we suggest that strategic adjustment is at the root of the survival strategies of these microstructures in a Burundian context dominated by insecurity and extreme poverty. The primary needs of these entities are at the root of the adjustment response to key resources provided by microfinance institutions to survive. Thus, the objective of this article is to explain how a microcredit beneficiary NPO aligns itself with the constraints of the lender. To this end, we propose an analysis grid of their 
adjustment strategies from a sample of 150 NPOs who are beneficiaries of micro-credits created from 1992 to 2011. We show that their internal organization is at the base of their efficiency. This organizational asset has certain unique characteristics and is the result of strategic alignment.

\section{References}

Ansoff, H. I. (1965). Corporate strategy. An analytic approach to business policy for growth and expansion. New-York: McGraw-Hill.

Baumard, P., Donada, C., Ibert, J., \& Xuereb, J. M. (2003). La collecte des données et la gestion de leurs sources. In Thiétart, R.-A. (Ed.), Méthodes de Recherche en Management (pp. 224-256). Paris: Dunod.

Bazzoli, L., \& Dutraive, V. (2006). Fondements pragmatistes de l'institutionnalisme en économie: théorie de la connaissance et théorie de l'action chez Veblen et Commons. Revue de Philosophie ÉConomique, 13, 123-153.

Boyer, A., Horigoyen, G., Thépot, j, Tournois, N., \& Védrine, J. P. (2005). Les fondamentaux de l'entreprise. Marketing, Production, Finance, RH, Stratégie (3ème éd.). Paris: Editions d'organisation.

Burns, T., \& Stalker, G. M. (1961). The Management of Innovation. London: Tavistock.

Chandler, A. D., \& Hikino, T. (2009). Scale and Scope: The Dynamics of Industrial Capitalism. Cambridge, Massachusetts: Harvard university.

Chiapello, E., \& Desrosières, A. (2006). La quantification de l'économie et la recherche en sciences sociales: paradoxes, contradictions et omissions. Le cas exemplaire de la positive accounting theory. Sous la direction de Duvernay, F. E. (Ed.), L'économie des conventions, méthodes et résultats (Recherches, Tome1, pp. 297-310). Paris: La découverte.

Etien, A. (2006). L'ingénierie de l'alignement: Concepts, Modèles et Processus. La méthode ACEM pour la correction et l'évolution d'un système d'information aux processus d'entreprise. Retrieved from https://tel.archives-ouvertes.fr/tel-00135753

Friedman, M. (2004). Friedman and money in the 1930s'. History of Political Economy, 36, 521-531. https://doi.org/10.1215/00182702-36-3-521

Greffe, X., \& Simonet, V. (2008). La survie des nouvelles entreprises culturelles: le rôle du regroupement géographique. Recherches Economiques de Louvain, 74, 327-357. https://doi.org/10.3917/rel.743.0327

Hafsi, T., Séguin, F., \& Toulouse, J. M. (2000). La Stratégie des Organisations: Une Synthèse (2ème éd.). Montréal: Editions transcontinental.

Hayek, F. A. (2002). Economie et connaissance. Cahiers d'économie Politique, 43, 119-134. https://doi.org/10.3917/cep.043.0119

Helfer, J.-P., Kalika, M., \& Orsoni, J. (2004). Management Stratégie et Organisation. Paris: Edition librairie Vuibert.

Hellriegel, D., \& Slocum, J. W. (2006). Management des Organisations (2ème éd.). Bruxelles: De Boeck \& Larcier S. G.

Henderson, J., \& Venkatraman, N. (1993). Strategic Alignment: A Model for Organizational Transforming via Information Technology. New-York: Oxford University Press.

Henderson, J., \& Venkatraman, N. (1999). Strategic alignment: Leveraging information technology for transforming organizations. IBM Systems Journal, 38(283), 472-484. https://doi.org/10.1147/SJ.1999.5387096

Jakubowicz, A. (2002). L'adaptation Psychologique, pp. 247-250. Paris: Encyclopædia universalis France.

Kaplan, R., \& Norton, D. (1992). The balanced scorecard-measures that drive performance. Harvard Business Review, 71-79.

Laville, F. (1999). La Dimension Cognitive des Organisations Économiques. Paris: EHESS

Laville, F. (2000). La cognition située: Une nouvelle approche de la rationalité limitée. Revue Économique, 51(6), 1301-1331.

Lavoie, M. (2005). Les hétérodoxies ont-elles quelque chose en commun? Économie et Société, 35, 95-114.

Lawson, T. (2007). The nature of heterodox economics. Cambridge Journal of Economics, 37, 1-23.

Miles, R. E., \& Snow, C. C. (1984). Fit, failure and the hall of fame. California Management Review, 26, 10-28. https://doi.org/10.2307/41165078 
Mintzberg, H., \& Waters, J. (1985). Of strategies deliberate and emergent. Strategic Management Journal, 6, 257-272. https://doi.org/10.1002/smj.4250060306

Monnoyer-Longé, M.-C., \& Lapassouse Madrid, C. (2007). Intégrer les sites web dans les stratégies. Concept et modèle. Revue Française de Gestion, 4(173), 145-155. https://doi.org/10.3166/rfg.173.145-155

Müller, D. B., Boaler, H.-P., \& Baccini, P. (2004). Long-term coordination of timber production and consumption using a dynamic material and energy flow analysis. Journal of Industrial Ecology, 8(3), 65-87. https://doi.org/10.1162/1088198042442342

Orlove, B. (2005). Human adaptation to climate change: a review of three historical cases and some general perspectives. Environmental Science \& Policy, 8, 589-600. https://doi.org/10.1016/j.envsci.2005.06.009

Papp, R. (2001). Strategic Information Technology: Opportunities for Competitive Advantage. Hershey, PA: Idea group publishing. https://doi.org/10.4018/978-1-87828-987-2

Pfeffer, J., \& Salancik, G. R. (1978). The External Control of Organizations: A Resource Dependence Perspective. New York: Harper \& Row.

Porter, M. E. (1980). Competitive Strategy Techniques for Analyzing Industries and Competitors. Toronto: Free press.

Prahalad, C. K., \& Hamel, G. (1989, mai - juin). Strategic intent, Harvard Business Review, 63-76.

Prahalad, C. K., \& Hamel, G. (1990, mai - juin). The core competitive of corporation. Harvard Business Review, 79-91.

Richez-Battesti, N., \& Oswald, P. (2010). Configuration de gouvernance et stratégie institutionnelle du « faire ensemble». Une analyse à partir d'un groupe de tourisme social. Politiques et Management Public, 27(1), $31-51$.

Robbins, S., \& DeCenzo, D. (2004). Management. L'essentiel des concepts et des pratiques. Paris: Pearson Education France.

Rousseau, D. M. (2001). The idiosyncratic deal: flexibility versus fairness. Organizational Dynamics, 29(4), 260-273. https://doi.org/10.1016/S0090-2616(01)00032-8

Séguin, F., Hafsi, T., \& Demers, C. (2008). Le Management Stratégique. De L'Analyse À L'Action. Montréal: Les Editions transcontinental.

Stajkovic, A. D., \& Luthans, F. A. (1997). A meta-analysis of the effects of organizational behavior modification on task performance. Academy of Management Journal, 40, 1122-1149.

Thevenet, L. H. (2009). Proposition d'une modélisation conceptuelle d'alignement stratégique: La méthode INSTAL. Thèse. Université Panthéon-Sorbonne-Paris I. Retrieved from http://tel.archives-ouvertes.fr/tel.-00466827

Venkatraman, N., \& Camillus, J. C. (1984). Exploring the concept of fit in strategic management. Academy of Management Review, 19(3), 513-525.

Venkatraman, N. (1989). The concept of fit in strategy research: toward verbal and statistical correspondence. Academy of Management Review, 14, 423-444. https://doi.org/10.5465/amr.1989.4279078

Wernefelt, B. (1984). A resource based view of the firm. Strategic Management Journal, 5, 171-180. https://doi.org/10.1002/smj.4250050207

Zimmerman, K. (2002). Using the balanced scorecard for interorganizational performance management of supply chains: A case study. In Seuring, S., \& Goldbach, M. (Eds.). Cost Management in Supply Chains (pp. 399-415). Heidelberg: Physica-Verlag. https://doi.org/10.1007/978-3-662-11377-6_24

Zimmermann, J. A., \& Stevens, B. W. (2006). The use of performance measurement in South Carolina nonprofits. Nonprofit Management and Leadership, 16(3), 315-327. https://doi.org/10.1002/nml.109 